\title{
LAND USE AND COVER CHANGES IN THE EVACUATED RURAL AREAS (THE CASE OF BIESZCZADY MTS)
}

The area of Bieszczady Mts, located in south-eastern Poland, constitutes a particular instance of the territories which were subject to abrupt depopulation. In 1946, namely, mass displacement of population occurred there. The most drastic evacuation action was carried out in the villages of the south-eastern part of the region. The resulting local disappearance of the anthropogenic pressure for the period of several decades entailed enormous changes, primarily in land use and land cover. These changes will be reported in the present paper for the specific case of the former village located in the valley of Caryński creek. This case is a representative instance of return to natural conditions (re-naturalization) of the valley biotope in the situation of the complete and quite durable disappearance of the anthropogenic pressure.

The purpose of the study presented in the paper was the analysis of changes in land use and in the most important elements of land cover in three time instants $(1852,1966$ and 1996)* The state of things as of the middle of 19 th century was reconstructed on the basis of Austrian cadaster plans (of 1852) of the scale of 1:2880, which were generalized and transformed to the scale of 1:10 000. Cadasters updated in 1966 served as the basis for reconstruction of the geographical environment of the Carynski valley in the 1960s. During the field studies carried out in 1996 the detailed maps of land use were elaborated. Thus, the present reaches of forests, permanent grasslands, settlement areas, waters and some anthropogenic forms (stone piles, field borders, agxicultural terraces) were introduced onto the 1:10 000 maps of 1983.

\footnotetext{
* The text of the paper was written on the basis of the M.A. dissertation elaborated under the tutorship of Wojciech Lewandowski at the Faculty of Geography and Regional Studies of the University of Warsaw.
} 


\section{LOCATION OF THE AREA}

The area analysed occupies the total surface of approximately 2.4 sq. $\mathrm{kms}(3.1 \mathrm{~km}$ by $0.8 \mathrm{~km})$, along the valley axis, within the settlement cluster of the former village and the neighbouring areas (Fig. 1). Maximum altitude difference is $250 \mathrm{~m}$ (between 640 and $890 \mathrm{~m}$ a.s.l.). The main water flow is Caryński creek of $8 \mathrm{~km}$ of total length, with $3.2 \mathrm{~km}$ of it contained within the area studied. The sources of Caryński are located at $1050 \mathrm{~m}$ a.s.l. In the upper part of its course the creek flows northwards (sloping by $137 \%$ ), to then change the flow direction to north-western, with the slope decreasing to $35 \%$.

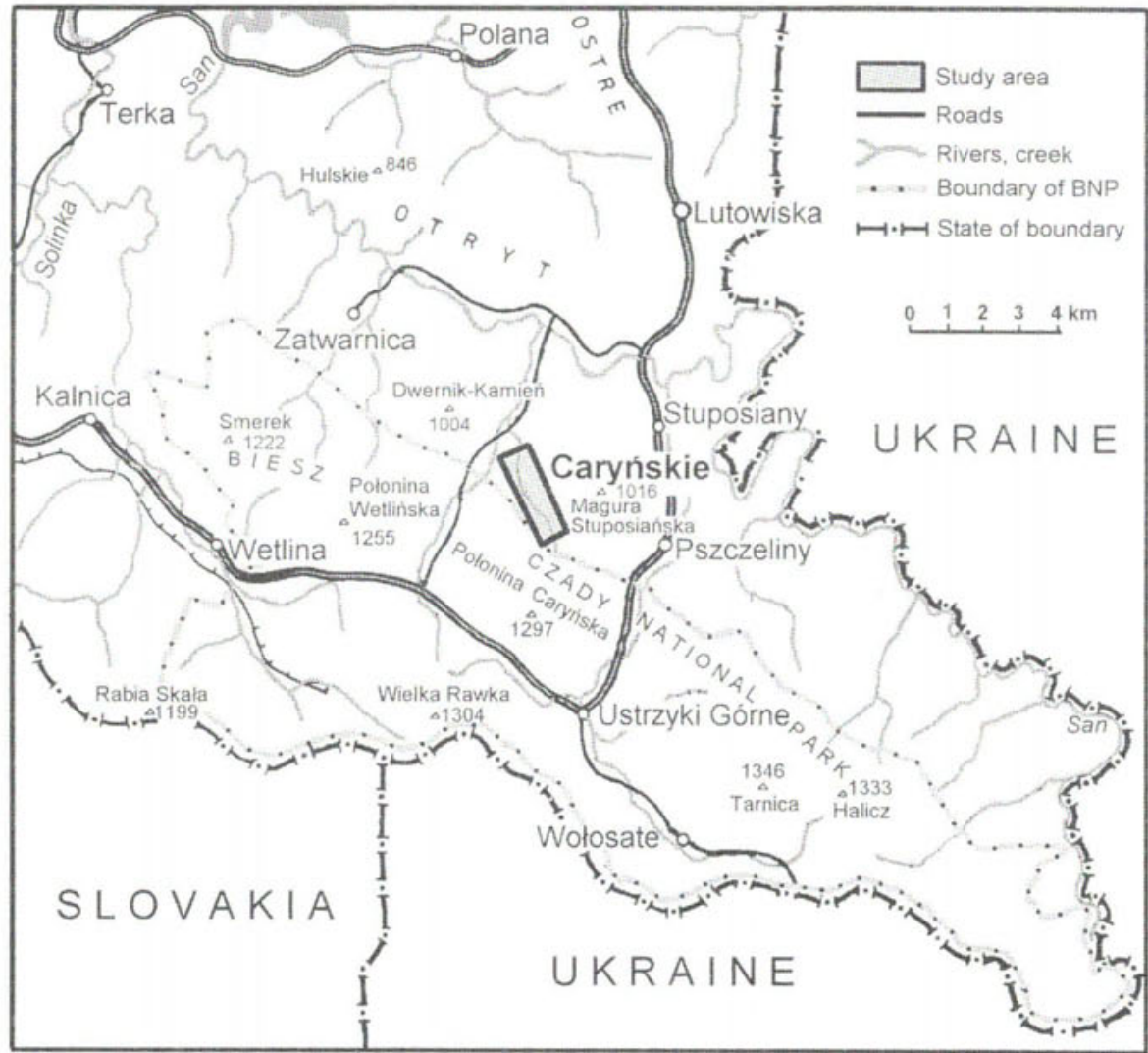

Fig. 1. Scheme of location of the study area.

The study area is located within the lower belt of submontane forest (600-1150 $\mathrm{m}$ a.s.l.), whose lower parts (up to some $800 \mathrm{~m}$ a.s.l.) are occupied by the separate kind of natural domain, the anthropogenic domain of the valleys. It emerged due to the felling of forests in this region in the 15 th- 
16 th centuries. It is here that almost entire economic activity of the villages was concentrated (excepting the mountain meadow grazing). The domain of the valleys is the locus of mutual penetration of the lowland and mountainous plant species and communities. The area in question - similarly as other valley systems - is characterized by the dense mosaic of the transitory communities and various stages of succession, often difficult to classify unambiguously (Zarzycki, Głowaciński, 1986).

\section{THE SETTLEMENT PROCESS}

The valley of Caryński was inhabited by Boykos since as early as 16th century. Their origins are related to the Valachian migrations, started most probably by the colons from Galician Ruthenia, who, having passed over to the southern side of the Carpathians (in 11th-12th centuries) settled on the territory of Hungary of that time. At the beginning of 14th century the watershed of upper Tisa river became the mixing pot of the Balkan, Roumanian and Ruthenian ethnic elements. Within the area of Bieszczady Mts the assimilated Ruthenian-Valachian poeples underwent Ruthenization and gave the origins for Boykos - the ethnographic group of Ruthenian mountaineers. In spite of an important economic backwardness, archaic features of their culture or lack of distinct group identity, Boykos were the most homogeneous Ukrainian group among the Carpathian mountaineers (Bieszczady...;, 1992; Derwich, 1990).

The first information on the village of Caryńskie dates back to 1620 . The village of our interest formed together with the villages of Berehy Górne, Nasiczne and Dwerniki the estate being a part of the Sobienie lands belonging to Kmita family.

Table 1

Ownership structure of Caryńskie village (in hectares) in 1868

\begin{tabular}{|l|c|c|c|c|c|}
\hline Land owned by & \multicolumn{5}{|c|}{ Land use forms } \\
\hline \multicolumn{1}{|c|}{ Arable fields } & meadows & orchards & pastures & forests & totals \\
\hline Peasants & 3545 & 1456 & 2831 & 219 & 8051 \\
Manor & 92 & 40 & 1186 & 7458 & 8776 \\
Totals & 3637 & 1496 & 4017 & 7677 & 16827 \\
\hline
\end{tabular}

Own calculations after Stownik.., 1995

At the instant the areas here considered were taken over by the Soviet authorities in 1944 the resettlement of Poles to the so called Regained Territories in the West and of the Ukrainian population to the Soviet Union started. This particular action did not encompass yet Caryńskie village, in which the forced displacement took place later, at the turn of May 1946. The resettlement was carried out on the denominational basis, and almost 
all the inhabitants — including Poles - were Greek-Catholics (uniates), and thus treated as Ukrainians (Stownik..., 1995).

Table 2

Population of Caryńskie

\begin{tabular}{|c|c|c|}
\hline Year & Number of houses & $\begin{array}{c}\text { Number } \\
\text { of inhabitants }\end{array}$ \\
\hline 1785 & no data & 330 \\
1857 & no data & 540 \\
1921 & 63 & 402 \\
1938 & no data & 503 \\
1946 & 80 & approx. 500 \\
1996 & 1 & 1 \\
\hline
\end{tabular}

After Stownik.., 1995

Within the territory of the village there were, in particular, the GreekCatholic St. Demetrios Great Martyr's church of 1775, the church graveyard in the confluence of Caryniski and Carynczyk creeks (0.54 hectare), and another graveyard ( 0.3 hectare), the latter having been entirely destroyed during construction of the tar road in 1970s.

Thus, after the end of World War II the valley of Carynski was uninhabited. In 1960 s and 1970 s the sheep pasturing started to be conducted there (in 1969 some 750 sheep and 10 heifers grazed on 200 hectares), and along with this - a local felling of shrubs and young trees (primarily alder growing on former agricultural lands) was started. In some places the monocultural stands of spruce were established. In 1970s the refuge "Koliba" was constructed on Przysłup pass.

There are very few traces now of the structures dating from before the war. The ruins of indulgence chapel were preserved within the church graveyard, along with some 100 overgrown earth graves, three tombstones and the wall surrounding the cemetery. One can still find in the closest vicinity a ruined chapel, a sandstone cross (dated 1911), and the oak cross of 1938. Currently the area of the "village", belonging to the sheriffship of Dwernik, is 1583.9 hectares, including 1438.9 hectares of forest (Bieszczady..., 1992; Kłos, 1993; Stownik.., 1995).

\section{CHANGES OF SPATIAL STRUCTURE}

In the period of intensive human economic activity the area studied was characterized by the striped structure of land. Almost every stripe (field unit) of land - stretching between the creek bed and the steep forested slopes of the two sides of the valley - was divided into parcels, belonging to different owners. The stripe setting was characteristic for the majority of 
the Carpathian villages, as securing the possibility of a just division of land. In the pre-war period the area of the village was partitioned into small ownership plots.

In the middle of 19th century the arable fields dominated (more than $50 \%$ ), forming belts along the medium altitude of the slopes (Fig. 2a). This domination was especially pronounced on the slopes of Magura Stuposiańska - less steep and getting more sun. The hay-producing meadows (more than $18 \%$ of total surface) would primarily occupy the flat, easily accessible and most humid creek-bed adjacent areas, as well as small and irregular patches on the south-western slopes of the valley. In some cases the hay-producing meadows accompanied - in the form of narrow belts the road and creek cut-ins opening into the valley. Pastures would cover rather small areas, forming a broad belt at the border with the forest - in the majority of cases on the north- eastern slopes. In the creek-bed adjacent part (with highly humid habitats) and towards the Połonina Caryńska mountain (low insolation) pastures were only sporadic. At that time the border between fields and forests would be located within Caryńskie at the altitude of $700-750 \mathrm{~m}$ a.s.l. (Połonina Caryńska) and $700-850 \mathrm{~m}$ a.s.1. (Magura Stuposiańska).

The devastating, large-scale exploitation of forests in Bieszczady Mts, conducted at the turn of 20th century, including the area of Caryniskie and its vicinity, influenced exceptionally disadvantageously the specie composition of the stands and the age distribution of trees (cutting of the most valuable trees, leaving of the substandard parts of stands, replacement by spruce), as well as their quality, since the selective clearing would leave the sick and deformed individuals while choosing only the best ones (Bieszczady..., 1992; Stownik..., 1995). The consequence of such activity was raising of the lower border of the forest, within which artificial pastures would emerge. This entailed a significant dismemberment of the forest areas (tearing away of the compact stands and areas), appearance of "islands" and groves.

During 20 years after the displacement of the population (i.e. in the 1960s) the land use pattern underwent a drastic change (Fig. 2b). Owing to natural self-sodding the arable land disappeared almost entirely - just one patch was left of 2 hectares of surface. It can be supposed that already at that time the composition of the overgrowth covering the former arable fields did not differ from the one of the plants growing on the previous permanent grasslands. The differences could only refer to the quantitative share of the papilionaceae, the herbs and grasses and to the compactness of the vegetation cover.

The pastures which appear due to self-sodding, and whose area increased by more than the factor of four (up to 67\%), developed in the middle and better insolated parts of slopes, where too low humidity was not advantageous for the expansion of the alder and the willows. The hay-producing meadows remained in only some places, amounting to a bit more than $3 \%$ of total surface. 


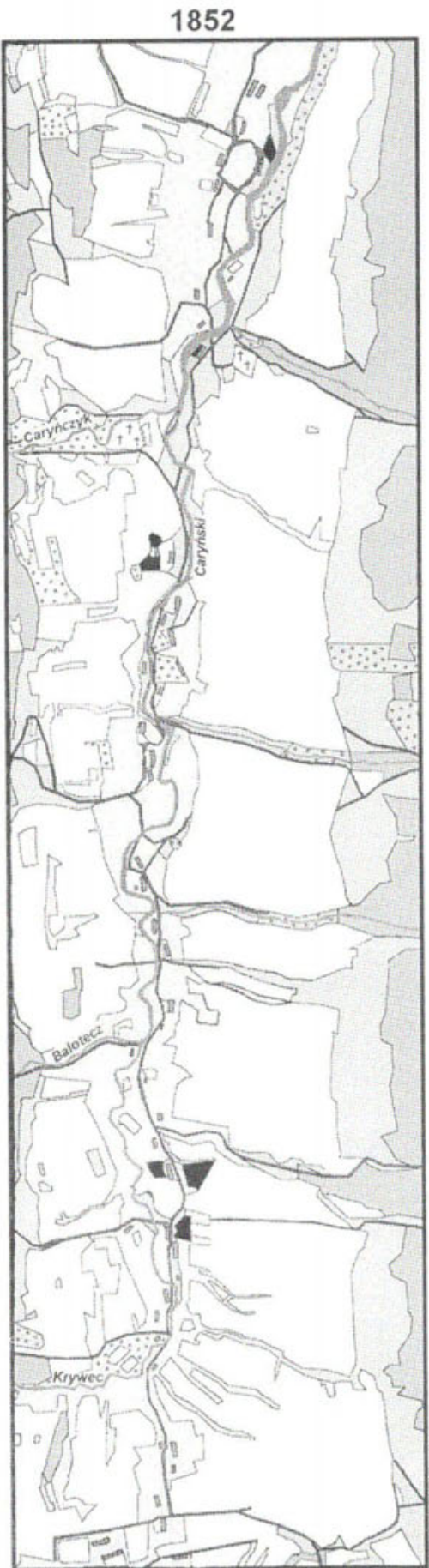

Fig. 2a
Forests

Pastures

Hay-producing meadows

Arable land

Artificial plantings

Orchards

Shrubby thickets

Tall shrubs and low trees

Overgrowing areas

Mature trees and tree group

- Pre-war roads

Present roads

- Pathways

Homestead tree plantings

- (mainly ashes)

- Fruit trees

Post-agricultural terraces and in-field balks

Structures

+ Cemeteries

$\sim$ Creeks

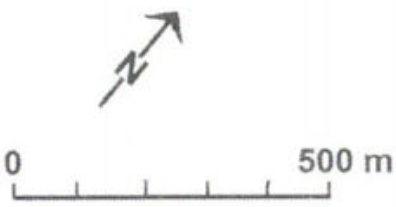

Fig. 2. Land use within the village of Carynskie a - as of 1852 (on the basis of Austrian cadastral plans of the scale of $1: 2880$ ), b - as of 1966 (on the basis of the cadastral plans updated in 1966), c - as of 1996 (on the basis of topographical map published by PPGK of the scale of 1:10 000 elaborated in 1983). 


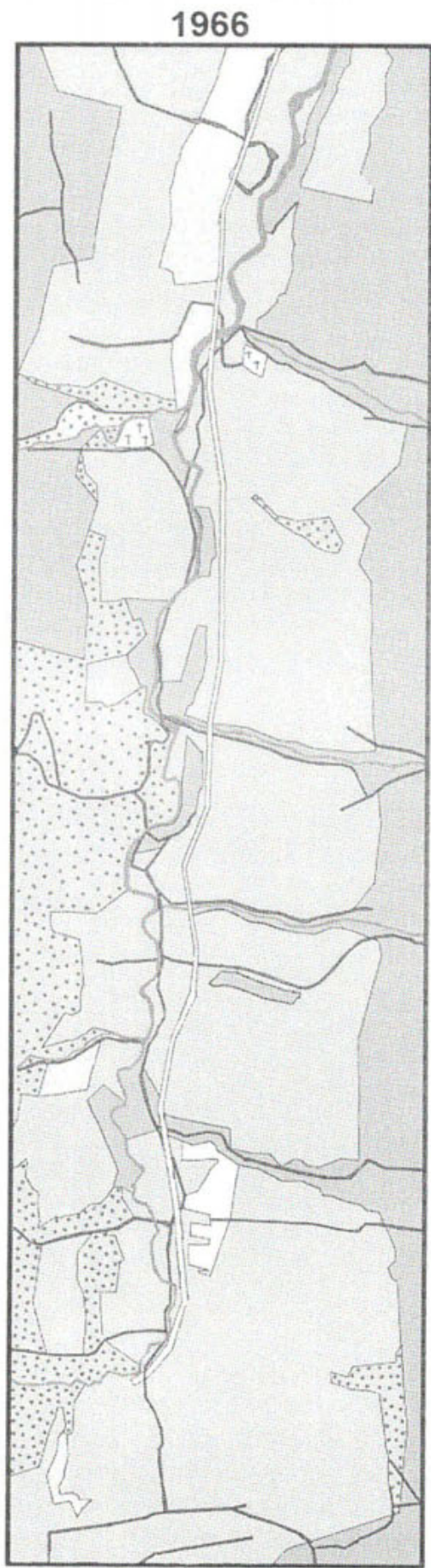

Fig. 2b

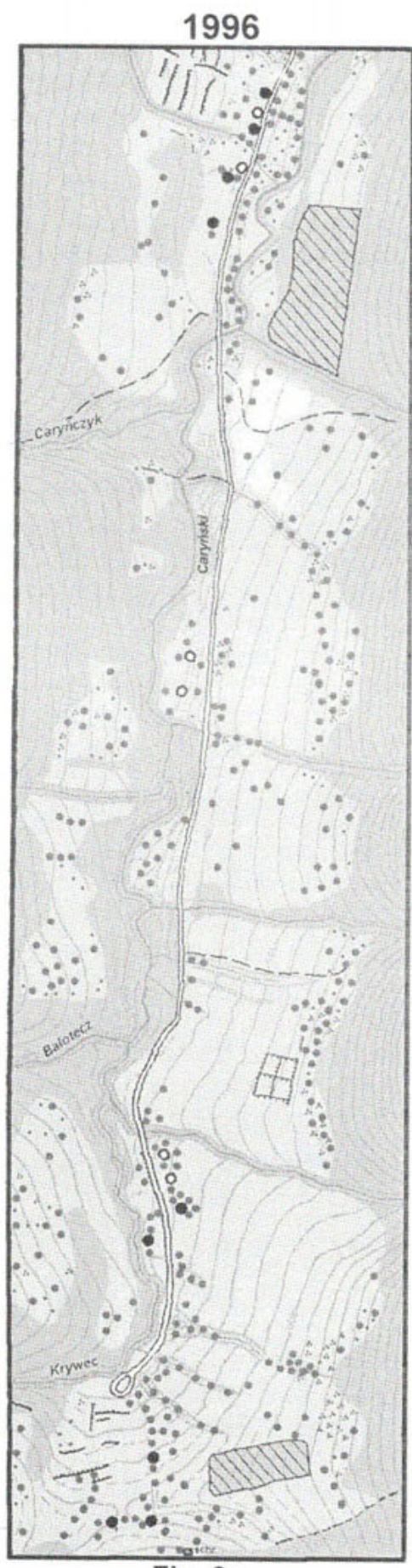

Fig. 2c 
Quite an important role in the course of the succession processes within the agrocoenoses in the 1960s and 1970s was played by sheep pasturing. The significantly increased volume of nutrients (animal excrements) entailed a change of the specie composition of the meadow communities. The mat- weed grasslands located within the highest belt of open space and not used for pasturing soon became the succession areas. The succession process, though, was slowed down either artificially (felling) or naturally (very dense mat-weed cover made self-forestation very difficult), see Nowak, Kostuch (1974). The descent and the smoothing of the lower forest border, forestation of the pastures and meadows located at higher altitudes, as well as growing over of the forest clearings resulted altogether in more than doubling of the surface occupied by forests. The field-forest border descended on the average by 20-50 $\mathrm{m}$ within the area studied.

In 1996 there was only one patch ( 3 hectares) of the hay- making meadow on the area of Caryńskie settlement. This meadow was established for the purpose of producing feedstuff for the Eastern Carpathian horses (Huculs) and in order to enhance the landscape value of the valley (Fig. 2c). The surface taken by pastures decreased significantly to the advantage of the almost twofold increase of forest area. Forest took the pastures over which trees started to grow in $1960 \mathrm{~s}$, in particular on the south-western slopes, descending by 30-70 $\mathrm{m}$ down to the very bottom of the valley. The fact that there have been much smaller changes in the course of the forest's lower border on the slopes below Magura Stuposiańska was caused by much greater intensity of pasturing. The border between the forest communities and the non-forest ones is now relatively fresh an unstable. One can observe currently there the succession stands of varying age and differentiated specie composition (mainly beech, spruce, birch and ash). The descent of the border between the agricultural and forest land is also demonstrated by the occasional cases of the pasture forms of old beech trees, having previously grown at the edges of pastures and being permanently deformed by the grazing animals - such trees are growing now in young beech stands.

It is very characteristic for the whole area of Western Bieszczady in the post-war period that a part of the fallow land is taken by the extremely aggressive alder trees, progressing both owing to root outgrowth and selfseeding. The artificial communities of alder are a perfect precursor for the climactic species. In the valley studied this process seems to have been effectively constrained, insofar as one observes now few places occupied by alder. On the other hand - the artificial spruce and birch plantings do occur there.

During the very intensive land use period a very important role was played by the in-field roads. They served first of all to transport farming equipment and the harvested crops from the higher located fields. Some roads were used to direct cattle and sheep to pastures, and within the forest areas they were used to transport wood from felling places. The spatial 
setting of roads in the valley of Caryński was quite typical and to a large extent dependent upon the shape of relief and the ownership structure. The main, hard surface road went along the bottom of the valley, crossing several times the creek. There were 19 ground-surface in-field roads on the slopes, perpendicular to the main road. Their total length was $11 \mathrm{kms}$, average density $-4.6 \mathrm{~km} / \mathrm{sq} . \mathrm{km}$. Sometimes they would go along the bottom of a creek flowing in a deep natural gully. Very limited number of bridges and culverts caused that roads would usually cross water flows through fords. In many places the sides of the ravines were strengthened with stone walls, of which some were preserved until today.

Besides the very important transport function the roads, constituting artificial beds of seasonal flows, played also the role of making the hydrographic network much denser. They had a bearing - along with the forest routes, paths and field furrows - on the intensification of the processes of erosion and water cycle on the slopes. The road ravines played the greatest role in formation of swells during intensive precipitation and spring thaws. It can be assumed on the basis of results from other studies carried out in Carpathian flysch valleys (Lach, 1984) that the intensive runoff in the area of Caryniskie was primarily caused by the very low permeability of the road surfaces. The average annual erosion intensity of line erosion ranged from 7 to $10 \mathrm{~mm}$ and would rapidly increase when the road gully sloped more than by $15^{\circ}$. Then also the average concentrated runoff velocity on the meadows and pastures amounted to $0.8-9 \mathrm{~cm} / \mathrm{sec}$., on the arable field $-13 \mathrm{~cm} / \mathrm{sec}$., and in the appearing holweg it would even exceed $1 \mathrm{~m} / \mathrm{sec}$.

Only a fraction of the previous roads are being used now. Due to sodding of the majority of them the uniform surface runoff - dominating again decreased, and its present values are probably equal to the runoff magnitude on the whole slope. Discontinuation of the use of holwegs resulted in the equalization of intensities of the degradation and accumulation processes. The stability and resilience to creep processes are currently homogeneous over the whole slope surface.

The very high degree of partitioning of fields in the valley of Caryński, expressed, in particular, through cultivation of one field stripe by numerous farmers, made it necessary to demarcate the ownership boundaries. The boundaries were delimited along some of the agricultural terraces (ploughed over), appearing during slope plowing, carried out conform to the altitude lines, as well as along the balks dividing fields. The terraces played also the very important role of the local denudation bases, modifying the water course on the slope and the effectiveness of some morphological processes. The structures existing on the slopes before 1946 decreased significantly the rate and the volume of denudation (by approximately 40\%), decreased the erosion force of precipitation waters, and brought about the domination of the dispersed runoff over the line runoff. The supply of the matter to the river beds was significantly reduced and the thus slowed down process of renewal of alluvia resulted in their intensive deepening (Lach, 1984). 
One can observe now in the valley of Caryński creek several terraces on the norther slope in the vicinity of Przysłup pass and on the forest clearing to the north-west of the route leading to the peak of Połonina Caryńska. The forms were found in young forest stands which can be classified as post-agricultural forest terraces. Their vegetation cover is thinner, and the shape - in comparison with the meadow terraces - more akin to the original one (steeper slope of the quite distinct and higher escarpment). It can be deduced that the meadow terraces, being destroyed, in particular, by field rodents, are slowly smotthed out over their whole surface, while the forest terraces are primarily subject to surface washing and line erosion, resulting in their dismemberment. Meadow terraces will continue to be smoothed out, although due to the developed root systems of plants and the significant sod thickness the smoothing process will go on very slowly.

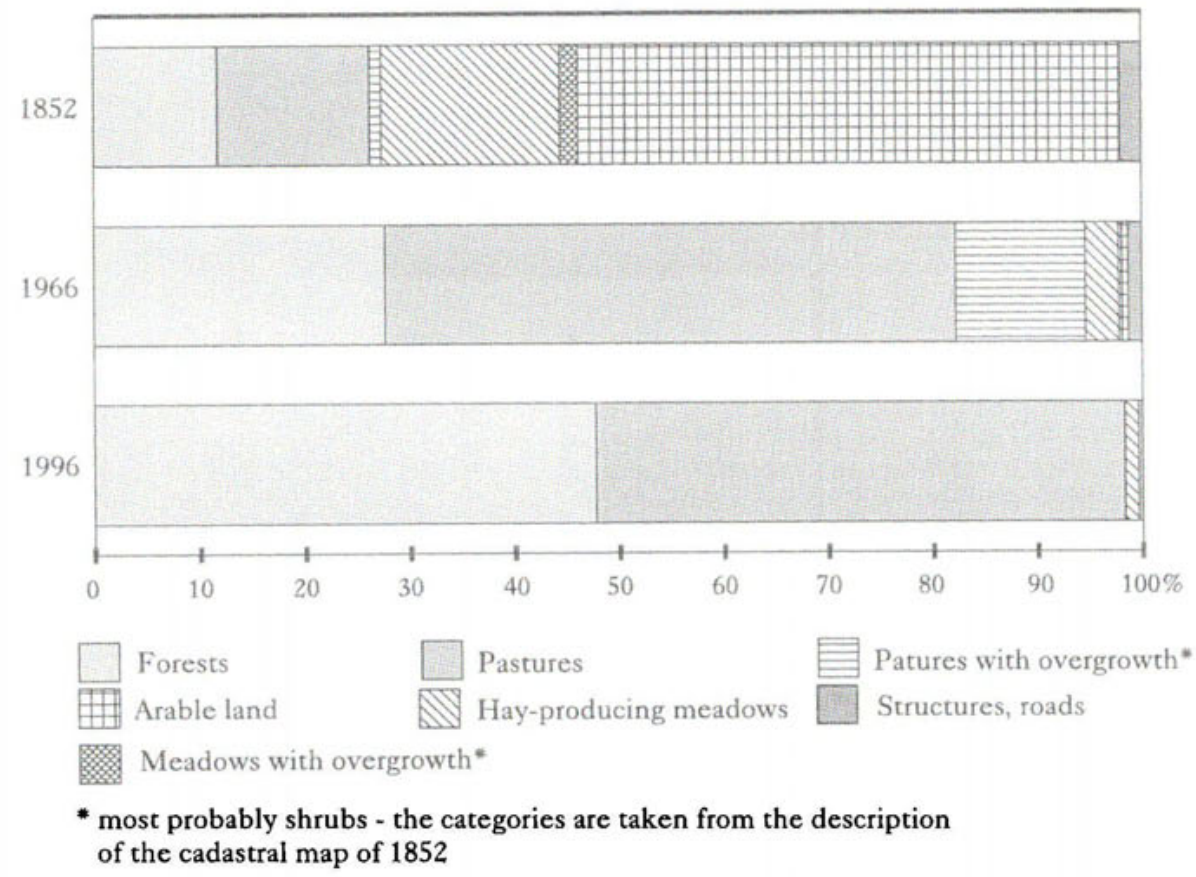

Fig. 3. Caryńskie - land use (in \%) in the years 1852-1996.

The valley abandoned by the population is characterized, as well, by the old trees planted within the homesteads (mainly sycamores, ashes and spruce). In numerous locations within the former village of Caryńskie both such individual trees and their groups of a dozen or so are observed. The situation is similar with respect to the spatial distribution of orchards. They were composed of a low number of trees, most often - primitive varieties of plum trees (damson, greengage and wild plum), pear trees (wild 
pear), apple trees and sweet cherry trees. They were found within the area of Caryńskie in many locations - starting with the river-bed adjacent places up to the lower border of the forest.

A number of characteristic stone mounds were also found. They were formed in older times with the ploughed out stones and located in the upper corners of cultivated fields. Their role was that of the border-defining landmarks. The degree of compactness, the amount of soil material and the well developed sod or bilberry overgrowth covering them all witness to the prewar origin of the stone piles.

\section{CONCLUSIONS}

Changes in land use and in land cover, which took place on the area of the former village of Caryniskie after the forced displacement of population in 1946, were characterized by a significant dynamics and occurred in stages. During the first 20 years the arable fields disappeared altogether due to self-sodding, and their place was taken by pastures. The specie composition of the post-agricultural communities approached that of the permanent grasslands. The field- forest border smoothed out and descended on the average by $20-50 \mathrm{~m}$. The second stage consisted primarily in the increase of forest areas and the simultaneous decrease of pasture area, over which forest expanded during 1960s. The present lower forest border is fresh and as yet not stable, and so the potential activities aiming at protection of the non-forest communities should consist in sporadic grazing or mowing, having primarily an ecological (interruption of the succession processes), and not economic significance. Introduction of the strict protection régime would cause that such areas be taken over by the expanding shrub and forest communities.

The morphogenetic processes, both surfacial and linear, have undergone a homogenization and slowing down over the whole area of the valley. The remnants of the pre-war road ravines and agricultural terraces will be subject to slow smoothing and evening out with the slope surfaces. Due, however, to strong influence of the sod layer this process will take a very slow course.

During the field studies clusters of synantropic plants were encountered, mainly in lower parts of the area, which are the persisting evidence of the village that existed there. These plants include the herb of Alpine sorrel (Rumicetum alpini), an indicator of intensive pasturing or fertilization most probably corresponding to the former enclosures for sheep, the communities of quitch (Agropyron repens) and of nettle (Urtica dioica) - along the road and in locations of former homesteads, the community of mint Mentha longifolia (the popular indicator plant showing the locations of buildings no longer existing), and the secondary thickets of bramble Rubus hirtus (very frequent on the slopes and along the roads). It was noticed that 
some places of concentrations of the plants, usually around the farms and near the huts, are the same as the locations of buildings on the cadastral plans. One could dare forwarding the statement that a future phytosociological study would provide an adequate basis for the reconstruction of the spatial outlay of the village, in spite of the fact that more than 50 years have elapsed.

\section{REFERENCES}

Bieszczady. Przewodnik, 1992, (Bieszczady. Guidebook; in Polish) Rewasz, Bosz, Pruszków.

Derwich A., 1990, Dzieje Bieszczadów. Przewodnik historyczny (The history of Bieszczady. A historical guidebook; in Polish), Ośrodek KTG PTTK w Ustrzykach Górnych.

Kłos S.,1993, Bieszczady, Wyd. Spółdzielcze, Warszawa.

Lach J., 1984, Geomorfologiczne skutki antropopresji rolniczej w wybranych częściach Karpat i ich Przedgórza (Geomorphological effects of the agricultural anthropogenic pressure in selected parts of the Carpathian Mts and their foothills; in Polish), Prace Monograficzne, LXVI, Wyd. Naukowe WSP, Kraków.

Nowak M., Kostuch R., 1974, Gospodarka ląkowa i pasterska w Bieszczadach Zachodnich (The meadow and pastoral economy in Western Bieszczady; in Polish), Problemy Zagospodarowania..., 13.

Pałczyński A., 1958, Wstępne badania geobotaniczne i florystyczne uzytków zielonych w Bieszczadach (Introductory geobotanic and floristic studies of the permanent grasslands in Bieszczady Mts; in Polish), Zeszyty Naukowe WSR, 12, Wrocław.

Stownik historyczno-krajoznawczy. Bieszczady. Część I: Gmina Lutowiska, 1995, (Historical and tourist distionary. Bieszczady. Part 1: Lutowiska commune; in Polish), ed. S.Kryciński et al.

Zarzycki K., Głowaciński Z., 1986, Bieszczady, Wiedza Powszechna, Warszawa. 